\title{
THE INEVITABILITY OF CORRUPTION FOR A STABLE PAKISTANI SOCIETY IN THE LIGHT OF QURAN \& SUNNAH
}

\author{
*Dr. Ahmad Raza \\ **Dr. Hidayat Khan
}

\section{Abstract:}

Corruption is a dishonest or illegal behavior especially by powerful people such as government officials or police officers. ${ }^{1}$ Corruption is a distraction to the face of society, and society has become a victim of recent misery. Every other person in our society is suffering from this disease. Political leaders, religious leaders, teachers, judges, employees, businessmen and the masses are suffering from this disease. While it is true to some extent that some political leaders have set records of corruption, it is not right to put it on the politicians alone. Corruption has reached its peak in every sector and institution here. Due to corruption, the wealth of the particular classes is increasing day by day and there is no one to hold them accountable. In such a dire situation, the oppressed and the masses are being humiliated in the oppression mill. Therefore, this curse should be abolished by Pakistani society and individuals should play their full role in the society as a whole. The key question is: What are the pros and cons of corruption in Pakistan and how is it possible for stability in the light of Islamic teachings to end corruption? Recommendations have also been compiled at the conclusion of the dissertation.

Key words: corruption, society, Inevitability, economy, stability.

*. Assistant Professor Dept. of Islamic Thought History \& Culture, 'Allāma Iqbāl Open University Islamabad

**. Associate Professor Dept. of Sharī'ah, 'Allāma Iqbāl Open University Islamabad 
Corruption adversely affects airplanes and people in any society. There are several types, such as moral corruption, social corruption, political corruption and financial corruption, etc. The most important of these is financial corruption. By this people's goods are consumed illegally. The property and possessions of the weak, the helpless and the harmless are taken away. Public wealth is brutally plundered.

\section{Corruption in Pakistan}

Unfortunately, the prevalence of financial corruption is common in Pakistan. Not only is financial mismanagement done to the weak, but also with the state, the government treasury is severely damaged. In our society, it has become common for others to illegally seize goods, rob public money, receive bribes, steal taxes, steal electricity, cash back in government funds, and misuse of business and commerce. The occupation of the lands and property of the orphans, the weak, the widows and the plain-hearted human beings, not only to occupy public lands and property but also to exploit and misuse them, has become the cause of undesirable elements. Instead of authoritarian service the betrayal has begun. Instead of providing basic facilities to the people, he encourages patience. Instead of giving them peace, peace, better employment, education and health care, they suffer.

Corruption in Pakistan is in the government departments and then in the judiciary. According to the survey, the most affected by corruption in Pakistan are the government departments, followed by the judiciary, the legislative body, and the political respectively. The number of parties, the private sector and the media comes in. According to the report, forty percent of the people who spoke to Pakistan during the survey said that government departments were most affected by corruption. Fourteen percent said that in the most corrupt judiciary and legislative bodies, 12 percent said the private sector and political parties and eight percent said that the media is the most corrupt. $^{2}$ 


\section{Major sources of corruption}

The major sources of corruption in Pakistan are:

\section{Bribery}

Bribery is the taking of one's wealth, seeking money for a legitimate or unlawful act, or making an illegal demand. Bribery is common in our society. In the past, a bribe was given to a gentleman for carrying out an illegal act, but now the situation has deteriorated to such an extent that it has to be paid for legitimate work or for obtaining rights. The bribe takers demand bribes with great shame and pride, and if their demands are not obeyed, they will stop the proceedings in some way. It is only by bribing such people that their rights can be earned.

\section{Money Laundering \& Fake Accounts}

Money laundering leads to the loss of money to the national treasury by illegally transferring money to the foreign country. A fake or suspicious bank account is an account that is opened in the name of a person whose money is opened. The Joint Investigation Team, which is investigating the case for allegedly transferring billions of rupees abroad from these suspicious accounts, has submitted a report to the Supreme Court regarding the progress made so far. The report states that 107 fake More than Rs 54 billion from accounts transferred to other countries. 3 Former Chief Justice of Pakistan Asif Saeed Khosa said during the hearing of a fake accounts case that It is extremely difficult to conduct transactions through fake accounts. Fake accounts cannot open without the involvement of bankers. 4

\section{Anonymous Properties}

Anonymous are properties by corruption. Unseen are properties that are apparently owned by someone else and are actually owned by someone else. Such properties are purchased in the name of wives, children, relatives and servants. Many people choose this method to invest in their black money. Such individuals are interested in anonymous properties that are inadequate to buy income property. 


\section{Anonymous Act}

If the government suspects a property, the Anonymous Act can investigate under 1988. Under this law, a person making an anonymous transaction can be punished with 3 to 7 years imprisonment and a fine of $25 \%$ on the market value of this property. If a person provides false information of anonymous property, he may be fined up to $10 \%$ on the market value of the property and imprisoned for 6 months to 5 years. If a person cannot prove his or her ownership of the property, then the deceased government may be forfeited. ${ }^{5}$

\section{Causes of Corruption}

1. Because of the development of science and technology, our lifestyle has changed. Everybody wants to have a big house, a car, a house with all the perks, a servant, and a good bank balance. All this cannot happen with limited income and limited resources. That is why in the race to earn high income from illegal sources, people are getting involved in corruption.

2. Due to poverty, unemployment and rising inflation in Pakistan, people are also getting income from illicit means and corruption.

3. There is an extravagance in government expenditure which is due to the royal expenses of the rulers.

4. Government schemes are risky so corruption is consumed by financing.

5. The institutions and departments that have been set up to curb corruption are failing in their responsibilities. Rather, they are causing corruption, which we see and hear for days to come.

6. Our system of justice is lacking in attitudes. In the pursuit of justice, people are rubbing rubbish. The oppressor becomes powerful and the oppressor is not allowed. This is why corruption grows.

7. Tax collection arrangements are outdated and unsuccessful. Large manufacturers, capitalists, landlords and landlords pay tax due to which the burden of tax burden falls on the poor. This also increases corruption. 


\section{Islamic Teachings to Eliminate Corruption}

Man has been given the status of Ashraf al-Mukhlokhs and made him a living angel. He has a crown of excellence on his head and holds it to the position of Caliph. No other creature was granted such greatness. It is only by the grace of the Lord. All human beings have been ordered to live peacefully and peacefully with respect to humanity. He has been instructed to adopt virtue and avoid the evil morals. Prevention of corruption is inseparable for social stability and peace and security. That is why all forms of abortion are generally regarded as public and financial misconduct, especially in the light of God. He has been informed of the catastrophic consequences of corruption. Respect for humanity and human rights is given by humankind and given clear teachings about humanitarian aid. See these teachings below:

\section{Honesty}

In matters of humanity, trust and integrity are the basic attributes of nuclear morality. If anyone has the right, pay him with all honesty. The virtue of honesty in trust is invisible, such as how does a person handle one's finances? It is actually a test in which the self and the devil have to be subdued, and the truth is as if it were not settled. Have to return and this is what is called honesty. Trust and fidelity does not apply to wealth and property, but in all matters, the process of trust and integrity continues. For example, if one has a right over someone, it is also a good way to pay. If anyone knows the secret of anyone, then there is a possibility to hide it. It is also permissible to confine yourself to anyone and seek advice on personal matters. Even the true understanding of the Qur'an and Sunnah is a surety to the public. In all matters the intention of the intention is trustworthy, it is said:

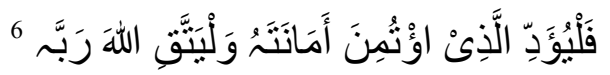

(And if one of you entrusts another, then let him who is entrusted discharge his trust [faithfully] and let him fear Allah, his Lord). 
The Prophet (peace and blessings of Allah be upon him) declared the trustee a symbol of faith and said:

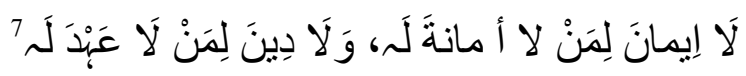

(There is no faith in the one who does not have the trust and in the person who is not bound by the contract, there is no religion).

Prior to the Prophecy of the Holy Prophet (SAW), the people of Mecca were well-known in Al-Qaeda in honesty, in Mecca, occupying the highest levels of integrity in trade and commerce. You used to protect people's security in such a way that the majority of the people of Mecca used to trust in their belongings. After the establishment of the state of Madinah, you as a ruler always protected the public trust. Allah spent his wealth on the servants of Allah.

The teachings concerning trusteeship include the payment of justice and other duties which the rulers owe to the people. Therefore, the Muslim ruler is obliged to carry out the affairs of the kingdom with all integrity. Keeping the affairs of the national treasury transparent and spending the money of the people on the people. Public misconduct that the government has with the government over time is undermined. Instead of spending money on the people, the wealth of the people continues to accumulate in the proposals of sovereignty.The Holy Prophet (SAW) said that whoever Allah Almighty has ruled over people and who betrays their rights, Allah will forbid Paradise on him. ${ }^{8}$

\section{Prohibition of eating material in a wrong way}

Allah Almighty has called financial misconduct a serious dislike. Eating or abusing others' property illegally can lead to eternal torment. The ruling is:

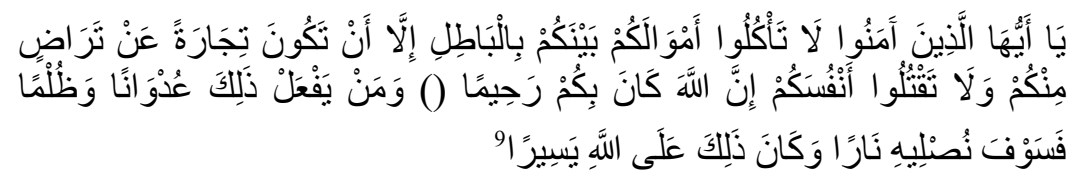


(O ye who believe! Eat not one another's goods in vain; except if there be consensus in the matter of trade between you. And do not kill yourself. Allah is Most Merciful to you. Whoever acts in such an act of excess and cruelty, we will soon burn him in the fire and this is very easy for Allah).

Believers are forbidden to eat, consume, or consume each other's wealth in the right way. However, in the case of trade, consent has been allowed to eat and use each other's goods in the event of mutual consent. Business matters are usually of the nature of a loan and there are certain conditions under which the document is prepared, in which the parties have certain rights. In this case it is lawful to eat or use each other's goods. The Qur'an has been ordered to document the business affairs:

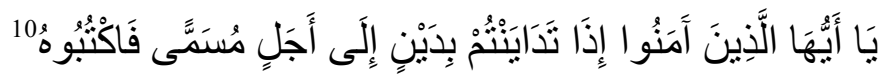

(O you who believe! When you deal with debt for a fixed term, write it down).

This Qur'anic order ensures the safety and security of the parties. This process eliminates the possibility of material loss. The Muslims of the Quran are brothers and sisters and financial treachery among the brothers is economic slaughter. Therefore, corruption in financial matters is a very serious crime and it has been promised.

\section{Weak to the weak killers}

The protection of the orphans' property and property is the responsibility of the perpetrator or the state. It is haraam to eat or dispose of orphans' goods illegally:

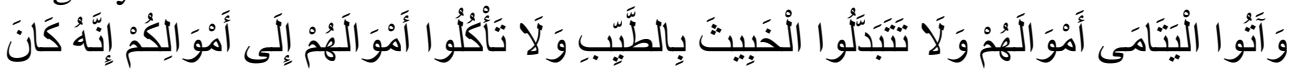

$$
\text { حُوبًَا كَبِيرًا } 11
$$

(And do not give the orphans their wealth and do not exchange the filthy wealth with pure wealth and eat their wealth with their wealth. Indeed this is a great $\sin$ ). 


\section{Good news of martyrdom on the safety of property}

The Prophet (peace and blessings of Allah be upon him) ordered the protection of wealth.Abu Hurairah narrates that a person from the Messenger of Allah questioned, "What should I do if a person wants to take away my possessions?" it is said by Hazrat Muhammad peace be upon him! Don't give him money. He said if they fight me? The Prophet (peace and blessings of Allah be upon him) said:You fight in your defense. He asked if he would kill me? The Prophet (peace and blessings of Allah be upon him) said that you would be a martyr. He asked if I could kill him? You said he would be hell. ${ }^{12}$

Ibn 'Umar (may Allah be pleased with him) said: The person who was killed to save his property is a martyr. ${ }^{13}$

\section{Elimination of Bribery}

Pre-Islamic bribery was common in the mainland Hijaz. The Arabs strongly believed in the Huns and considered them as the source of invisible power, making decisions and giving them money and gifts in return. It was common among the Jews that their nobles and religious leaders would receive money from the people and decide according to their wishes and take away their rights from the privileged and gave it to others. The bribe market was also hot to cover the rich's sins and protect them from legal grip. Apologies were sold to Christians. Religious leaders used bribes to issue certificates for cleansing of sins and to commit distortion in the Torah and the Gospel.

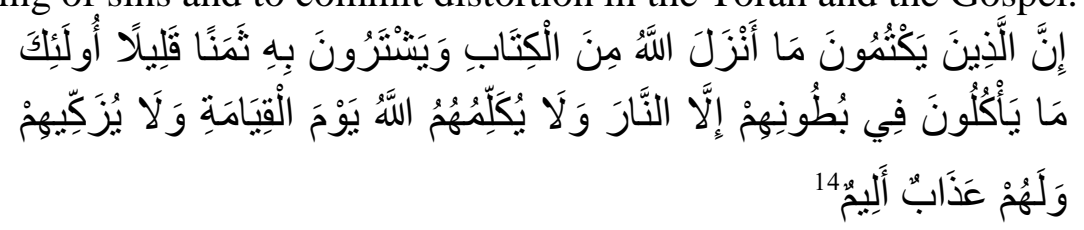

(Those who conceal the revelations of Allah and store a little in return for them they have only filled their bellies with fire, and Allah will not speak to them on the Day of Resurrection and purify them. Will not do and a painful doom for them).

It became clear that those who exchanged orders for bribes would face a painful punishment. Bribery is fire and will also be punished with the fire of 
hell. Even the believers are forbidden to do this forbidden act by the Lord. Allah says:

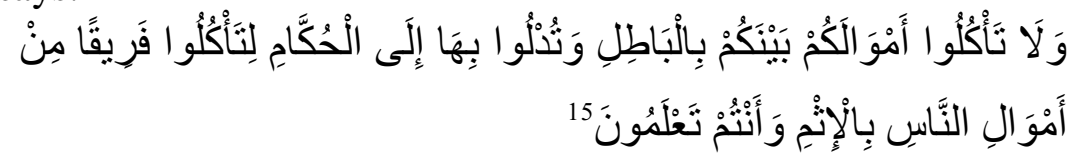

(And do not eat each other's wealth in a wrong way. And do not pass it on to the rulers to eat the wealth of people on the basis of sin, even though you know about it).

Pir kram Shah Al-Azhari concludes with the interpretation of the above verse: "It was also a convenient and effective way of eating the wealth of others, which is still to bribe the authorities and make decisions in their own right. The prohibition of this unclean way is mentioned separately. "16

The Holy Prophet (PBUH) has strongly condemned bribery, he said:

$$
\text { الر اشى و المرنشى كلاهما فى النار } 17
$$

(Both the bribe and the bribe will be in Hell).

It is forbidden for the bribe giver to seek help on the crime and the bribe taker assists in the crime and violates the law and gives the right to the rights of the other. Muslim government in Muslim society keeping the bribe market warm for the rulers and officials of the country is a sin, even the most immoral. Therefore, its end is very important.

\section{Warning to Unlawful Occupiers}

One type of corruption is illegal occupation of other's lands. The mafia, which occupies people's lands and public lands, is active at all times, making China kits, damaging billions of rupees to the people and the government. Such mafia has been promised severe punishment. The Prophet (peace and blessings of Allah be upon him) said that the person who took a mighty land in wrongdoing will, on the Day of Judgment, make the land up to seven classes in shackles. ${ }^{18}$

He also said: The person who takes the land of any one will be obliged to raise his clay and bring it to the surface ${ }^{19}$. 


\section{Conclusion}

If Pakistan's list of major problems is to be listed, it will be a top list of corruption. Corruption is an issue all over the world, but corruption in Pakistan has become such an issue that former Chief Justice of Pakistan Mian Saqib Nisar said in a statement that "corruption is one of Pakistan's biggest problems". ${ }^{20}$ What is being tried is spreading the same way. Where the majority of corrupt people deny it in full swing, a small number of them consider it their right. People are oblivious to their fate. Stopping them and counteracting their misconduct is imperative. Society can co-ordinate the misconduct of these people. As a matter of fact, we have to pay attention to this, which is to enhance the dignity of the country - Pakistan and the Muslim nation. Therefore, the corrupt elements must not only be identified but also accounted for. It is the social requirement and the rule of law.

\section{Recommendations}

i. Eliminating corruption from Pakistan is possible only when we criticize the corrupt people as well as look into our poor and try to stop the corruption around us.

ii. We have a universal duty to stop bribery. We are also willing to pay bribes for our legitimate purposes so that our work can be done easily and thus we become part of this corruption. Both the bribe and the giver are equally responsible. When we stop bribing and adopt legal procedures for our actions, corruption will be greatly reduced.

iii. Improve the political system of the country so that it can help to create problems of the people such as cheap justice and the formation of a society free from corruption.

iv. A transparent and effective system of accountability should be introduced so that every person and organization is accountable.

v. Corrupt elements should be punished according to the law. 
vi. Eliminate political interference in government jobs and adopt eligibility rules.

vii. Make national institutions free from politics and make people friendly.

viii. Raise awareness and awareness of bribery and corruption in the media through the media.

ix. Make people aware of the bribery and corruption in society and the principles of lawful and harām. 


\section{References}

1. https://www.merriam-webster.com/dictionary/corruption,accessed October 29,2018

- https://www.bbc.com/urdu/lg/pakistan, accessed October 29,2018

${ }^{3}$. https://www.google.com/search/fake accounts , accessed November 12,2018

${ }^{4}$-Nawa-e-Waqt, 18-06-2019

5. The Benami Transactions (Prohibition Act), 1988

${ }^{6}$-Al-Quran : 283

7 -Baehaqi, Ahmed Bin Hussain, al-Sunan, Berut, Dar Al-Kutub Alilmiah,1402AH,Hadtih:12690

8 -Qusheri, Muslim Bin Hajjaj, Sahih Muslim,Berut,Maktab Islami,Kitab al_imaan,Hadth: 363

9. Al-Quran, 4: 29-30

10. Al-Quran, 2: 282

${ }^{11}$-Al-Quran, $4: 6$

${ }^{12}$-Qusheri, Muslim Bin Hajjaj, Sahih Muslim,Berut,Maktab Islami,Kitab al_imaan,Hadth360

${ }^{13}$-Qusheri, Muslim Bin Hajjaj, Sahih Muslim,Berut,Maktab Islami,Kitab al_imaan,Hadth361

14. Al-Quran, 2: 174

15. Al-Quran, 2:188

${ }^{16}$-Al-Azhari, Pir Muhammad Karam Shah, Zia-ul-Quran, Ziaul Quran Publications Lahore,2002AD,Vol.1,pp233

${ }^{17}$-Bazzar, Ahmed Bin Amar, Almusnad, Berut, Maktab Islami, 1409AH, vol:3, pp 274

18 - Ahmaed Bin Hanbal, Almusnad, Berut, Maktab Islami,1406AH, pp244, Narrator: Saeed Bin Zaid

19 - Ahmaed Bin Hanbal, Almusnad, Berut, Maktab Islami,1406AH, pp247, Narrator: Saeed Bin Nofail

20 -Nawa-e-Waqt, 22-11-2019 